\author{
ks. Jerzy Swędrowski ${ }^{1}$ \\ Papieski Wydział Teologiczny w Warszawie - Collegium Joanneum
}

\title{
Tożsamość kapłańska według Jana Pawła II
}

\section{Streszczenie}

Tajemnica powołania jest zawsze odczytaniem relacji, w której sam Bóg zwraca się do człowieka i oczekuje od niego wspaniałomyślnej odpowiedzi. To spotkanie i dialog jest rodzeniem ku wspólnocie wiary, która obejmuje ludzi otwartych na realizm codziennej rzeczywistości i na wieczność Bożych przeznaczeń. Dar kapłaństwa służebnego staje się szczególnym narzędziem dla Kościoła, w którym głoszenie słowa i sprawowanie sakramentów wiodą do autentycznego i osobistego spotkania z Bogiem. Kapłan odpowiadając na wezwanie do służby Bożej, aby nieść Kościołowi skarb w „glinianym naczyniu” swojej egzystencji, staje się świadkiem wierności. W sakramencie święceń zostaje wyposażony, aby umiejętnie i skutecznie dzielić się "darem i tajemnicą", w których dokonuje się osobiste spotkanie z Bogiem i w nowy sposób rodzi się odpowiedzialność za wspólnotę Kościoła. Doświadczenie miłości i miłosierdzia bierze się z Eucharystii, która jest centrum życia kapłańskiego. To tutaj znajdzie się zaspokojenie ludzkich pragnień i umocnienie w sytuacjach kryzysowych. Kapłan rozwija się i umacnia na drodze miłości do Kościoła; na drodze naśladowania Chrystusowej Matki.

Słowa kluczowe: kapłaństwo, Eucharystia, wspólnota, Kościół

\section{Summary}

Priestly Identity According to John Paul II

The mystery of priestly call is always a reading into a relationship in which God himself turns to man and expects from him a generous response. This encounter and dialogue, between God and man, is a giving birth to a community of faith which embraces people who are open to the reality of everyday calling and to the eternity of God's destinies.

The gift of the ministerial priesthood becomes a special tool where the proclamation of the word and the administration of the sacraments lead to an

1 Ks. dr Jerzy Swędrowski (ORCID: 0000-0003-1386-8485) - kapłan diecezji łowickiej, proboszcz parafii św. Wawrzyńca DM w Kutnie. Prowadzi wykłady z homiletyki w WSD w Łowiczu; autor artykułów naukowych i publikacji homiletycznych. Adres do korespondencji: ul. Kard. St. Wyszyńskiego 4, 99-300 Kutno. E-mail: jswedrowski@diecezja.lowicz.pl. 
authentic and personal encounter with God. The priest, while answering the call to the service of God, becomes a loyal witness, ready to bring to the Church treasure in the "clay vessel" of his life. In the sacrament of Holy Orders, the priest is properly equipped to skillfully and effectively share the "gift and mystery" in which a personal encounter with God takes place and he assumes responsibility for the Church's community. The experience of love and mercy comes from the Eucharist, which is the center of priestly life. This is the source which will satisfy priestly human desires and gives strength in crisis situations. The priest develops and strengthens on the path of love for the Church; on the path of imitating Christ's Mother.

Keywords: Priesthood, Eucharist, Community, Church

Na jubileusz pięćdziesięciolecia swoich święceń kapłańskich papież Jan Paweł II ofiarował Kościołowi i ludziom dobrej woli świadectwo w publikacji Dar i tajemnica. Ten zapis nie jest jedynie sentymentalną retrospekcją, ale symptomatycznym wskazaniem na znaki tożsamości posługi kapłańskiej i postawy służby w Kościele. Pisząc o istocie kapłaństwa Papież z Polski zachęca, aby odkrywać tajemnicę bycia szafarzem Bożych tajemnic (por.1 Kor 4, 1-2); wreszcie zauważa:

\begin{abstract}
Szafarz nie jest właścicielem. Jest tym, któremu właściciel powierza swoje dobra, ażeby nimi zarządzał w sposób sprawiedliwy i odpowiedzialny. Tak właśnie kapłan otrzymuje od Chrystusa dobra zbawienia, ażeby je we właściwy sposób rozdzielał ludziom, do których jest posłany. Chodzi o dobra wiary. I dlatego też kapłan jest człowiekiem słowa Bożego, człowiekiem sakramentu, człowiekiem „tajemnicy wiary"2.
\end{abstract}

Jan Paweł II odsłaniał przez cały swój pontyfikat rzeczywistość powołania kapłańskiego i powinności, które są radosną odpowiedzią na Boże wezwanie. W swojej posłudze kontynuował dzieło Pawła VI, który w 1964 roku ustanowił Dzień Modlitw o Powołania Kapłańskie i Zakonne. Z tym wydarzeniem dokonującym się w czwartą niedzielę po Wielkanocy papież wiązał orędzie do wspólnoty Kościoła. Jan Paweł II wprowadził zwyczaj pisania listu do kapłanów na Wielki Czwartek; pierwszy taki list został opublikowany 8 kwietnia 1979 roku. Ukazał także swoją troskę o formację kapłańską w adhortacji apostolskiej Pastores dabo vobis z 25 marca

2 Jan Paweł II, Dar i tajemnica, Kraków 2005, s. 70. 
1992 roku. Przywołane dokumenty ukazują troskę Następcy św. Piotra o coraz skuteczniejszą recepcję zagadnień dotyczących posługi, formacji i tożsamości kapłańskiej.

\section{Kapłaństwo w jedności Eucharystii}

Pośród listów do kapłanów na Wielki Czwartek szczególne miejsce zajmuje List apostolski Dominicae cenae o tajemnicy i kulcie Eucharystii. Papież ukazuje ścisły i fundamentalny związek kapłaństwa służebnego z Eucharystią; stwierdza:

Kapłaństwo bowiem służebne i hierarchiczne zarazem, kapłaństwo biskupów i prezbiterów, a obok nich posługa diakonów - urzędy, które normalnie rozpoczynają się od głoszenia Ewangelii - pozostają w najściślejszym związku z Eucharystią. Eucharystia jest główną i centralną racją bytu sakramentu kapłaństwa, który definitywnie począł się w momencie ustanowienia Eucharystii i wraz z nią̧3.

Papież pokazuje, że w centrum życia kapłańskiego jest Msza święta, a właściwie kapłan odnajduje się i wyraża najpełniej wchodząc w tajemnicę obecności Jezusa w Jego ofierze. Eucharystia jest tajemnicą jedności, w której objawia się rzeczywistość Kościoła. Jan Paweł II zauważa:

Kościół jednakże nie urzeczywistnia się przez sam fakt zespolenia ludzi przez przeżycie braterstwa, do którego daje sposobność uczta eucharystyczna. Kościół urzeczywistnia się wówczas, gdy w owym braterskim zespoleniu i wspólnocie sprawujemy i celebrujemy Chrystusową Ofiarę krzyża, gdy śmierć Pańską głosimy, aż przyjdzie (por. 1 Kor 11,26$)^{4}$.

Powyższe słowa są symptomatyczne wobec współczesnego dyktatu socjologizmu i psychologizowania.

Papież w swoim liście przykłada szczególną wagę do świadomości sacrum w czasie sprawowania Ofiary Jezusa Chrystusa. Zauważa on, że sprawowanie Eucharystii nie jest sakralizowaniem ludzkich czynności, ale prawdziwym uczestnictwem w Zbawczej Ofierze; kapłan działa In persona Christi. To ostatnie sformułowanie jest używane i niejednokrotnie

3 Jan Paweł II, List apostolski Dominicae cenae o tajemnicy i kulcie Eucharystii do kapłanów na Wielki Czwartek 1980 roku, w: Jan Paweł II, Dzieła zebrane, t. 3, Kraków 2007, s. 912.

4 Jan Paweł II, List apostolski Dominicae cenae..., dz. cyt., s. 914 
nadużywane w przepowiadaniu, a może jeszcze częściej traktowane na sposób hasłowy. Uświadomienie sobie i uznanie jedyności Ofiary Chrystusa jest wchodzeniem na drogę jedności ze Zbawicielem. Według Jana Pawła II:

Uświadomienie sobie tego rzuca pewne światło na charakter i znaczenie Kapłana - liturga, który sprawując Najświętszą Ofiarę, działając „in persona Christi”, zostaje w sposób sakramentalny „a zarazem w sposób niewymowny” wciągnięty i wprowadzony w to najściślejsze Sacrum, w które zarazem wprowadza duchowo wszystkich uczestników eucharystycznego zgromadzenia ${ }^{5}$.

Papież zachęca do ciągłego pielęgnowania wymiaru sakralności, bowiem jest to jedyna droga wobec źle pojętego pluralizmu i indywidualizmu 6 .

Rok 1983 był w Kościele Jubileuszowym Rokiem Odkupienia i na Wielki Czwartek tego roku Papież pisze do kapłanów:

Jest to jak wiemy, dzień, w którym razem z Eucharystią zostało ustanowione przez Chrystusa służebne kapłaństwo. Zostało ustanowione dla Eucharystii, a przez to samo dla Kościoła, który jako wspólnota Bożego Ludu kształtuje się z Eucharystii ${ }^{7}$.

Właściwie we wszystkich listach do kapłanów brzmi soborowe stwierdzenie o Eucharystii jako źródle i szczycie życia Kościoła ${ }^{8}$. Aż do kresu swego pontyfikatu papież Jan Paweł II będzie zachęcał kapłanów, aby coraz pełniej wzbudzali świadomość realnej obecności Jezusa Chrystusa pod postaciami eucharystycznymi. W liście na Rok Eucharystii papież stwiedza:

Zarówno w samym celebrowaniu Mszy świętej, jak i w kulcie eucharystycznym poza Mszą świętą należy w pierwszym rzędzie umacniać żywą świadomość realnej

5 Jan Paweł II, List apostolski Dominicae cenae..., dz. cyt., s. 918-919.

6 Por. L. Łysień, Indywidualizm, w: Jan Paweł II. Encyklopedia nauczania społecznego, red. A. Zwoliński, Radom 2005, s. 201.

7 Jan Paweł II, List do kapłanówna Wielki Czwartek 1983 roku, w: Jan Paweł II, Dzieła zebrane, t. 3, Kraków 2007, s. 935.

8 Zob. Sobór Watykański II, Konstytucja dogmatyczna o Kościele Lumen gentium, w: Sobór Watykański II, Konstytucje, dekrety, deklaracje, tekst polski, nowe tłum., red. M. Przybył, Poznań 2002, s. 113. 
obecności Chrystusa, trzeba ją podkreślać tonem głosu, gestami, ruchami, całym zachowaniem 9 .

To całościowe i integralne zaangażowanie w sprawowanie świętych czynności staje się świadectwem, które pociąga wiernych; tutaj także wyraża się funkcja mistagoga.

W Liście do kapłanów na Wielki Czwartek 2004 roku papież wspomina z wdzięcznością 25 lat świętowania dnia kapłańskiego jako Następca św. Piotra i zauważa, że na Ostatniej Wieczerzy „zostaliśmy zrodzeni jako kapłani"10. To określenie każe spojrzeć na kapłaństwo jako na rzeczywistość nierozerwalnie związaną z Eucharystią. Ujawnia się w nim natura kapłaństwa, które nie funkcjonuje i nie spełnia swojej roli bez Eucharystii. W tym samym liście papież zwraca uwagę, że Eucharystia na charakter apostolski, w sensie powierzenia go apostołom, ale także dla umocnienia wierzących, dla ich duchowego wzrostu ${ }^{11}$. Jedność z Chrystusem w Eucharystii pobudza do niesienia darów sakramentalnych wspólnocie Kościoła, a jednocześnie czerpania duchowych mocy i znajdowania swojego miejsca. To odnajdowanie swego miejsca i powinności nie ma nic wspólnego z ludzkim wywyższaniem się, ale coraz pełniejszym odczytywaniem swojej tożsamości. Papież pisze: „Eucharystia, jak kapłaństwo, jest darem Boga, «który przewyższa zdecydowanie władzę zgromadzenia»"12. Podkreśla on znaczenie sukcesji apostolskiej, jak również uświadamia, że kapłan sprawuje Ofiarę Chrystusa w imieniu całego ludu. Jawi się tutaj specyficzna jedność kapłana z wierzącymi, dla których kapłan posługuje, a jednocześnie ich odpowiedź, choćby w kwestii modlitwy o powołania.

\section{Powołanie - udziałem w pełni życia}

Pośród dzieł, które pozostawił papież Jan Paweł II szczególnego znaczenia nabiera posługa krzewienia powołań. Chodzi tutaj o powołania do kapłaństwa i życia zakonnego, ale także o realizację powołania

9 Jan Paweł II, List apostolski Mane nobiscum Domine, Kraków 2004, s. 18.

10 Jan Paweł II, List do kapłanów na Wielki Czwartek 2004 roku, w: Jan Paweł II, Dzieła zebrane, t. 3, Kraków 2007, s. 1042.

11 Por. Jan Paweł II, List do kapłanów na Wielki Czwartek 2004 roku, dz. cyt., s. 1042-1043.

12 Jan Paweł II, List do kapłanów na Wielki Czwartek 2004 roku, dz. cyt., s. 1043. 
chrześcijańskiego w życiu każdego ucznia Jezusa Chrystusa. Jedną z form tej posługi były listy na niedzielę Jezusa Chrystusa Dobrego Pasterza. W liście na XIX Światowy Dzień Modlitw o Powołania papieżukazuje perspektywę powołania jako wezwanie do pełni życia. Wychodząc od słów Pana Jezusa, który mówi: „Ja przyszedłem po to, aby owce miały życie i miały je w obfitości" (J 10, 10), Jan Paweł II widzi w Kościele przestrzeń przyjmowania i budzenia życia. Podkreśla rolę Ducha Świętego, który przynosi wszelkie dary; On pobudza do rozumienia słowa Bożego, sakramentów i powołań w Kościele, jako istniejących dla życia. Pośród tych darów papież ukazuje kapłaństwo służebne: Darem, który - mocą święceń przewyższa wszystkie inne dary, jest kapłaństwo służebne, uczestniczące w jedynym Kapłaństwie Chrystusa, który złożył samego siebie w ofierze na krzyżu i nadal ofiarowuje siebie w Eucharystii za życie i zbawienie świata ${ }^{13}$. Podkreślenie wyjątkowości daru kapłaństwa służebnego jest wezwaniem do gorliwej troski o rozwój życia duchowego; papież w tym kontekście mówi o uczestnictwie w Bożej płodności ${ }^{14}$.

W roku poprzedzającym jubileusz roku 2000 Ojciec Święty oparł swoje orędzie na dzień powołań na słowach Modlitwy Pańskiej. W perspektywie wezwania „Święć się imię Twoje” wskazał drogę odkrywania powołania, jak również sposób jego realizacji. Tą drogą jest dążenie do świętości. Papież mówi: „Świętość - dar, o który trzeba nieustannie prosić - stanowi najcenniejszą i najskuteczniejszą odpowiedź na głód nadziei i życia we współczesnym świecie"15. Zachęca do szerokiego spojrzenia na przestrzeń życia osobistego, małżeńskiego i rodzinnego, aby w Chrystusie odkrywać pragnienie realizacji zamysłów Bożych. Tylko w harmonijnej współpracy wszystkich, którzy stanowią Kościół Jan Paweł II widzi wypełnienie woli Ojca. Przecież sam Jezus Chrystus każe zwracać się do Ojca we wspólnocie; zachęca, aby wołać „Ojcze nasz”.

13 Jan Paweł II, Orędzie na XIX Światowy Dzień Modlitw o Powołania - 1982 roku, w: Jan Paweł II, Dzieła zebrane, t. 4, Kraków 2007, s. 583.

14 Por. Jan Paweł II, Orędzie na XIX Światowy Dzień Modlitw o Powołania - 1982 r., dz. cyt., S. 583.

15 Jan Paweł II, Orędzie na XXXIV Światowy Dzień Modlitw o Powołania - 1999 roku, w: Jan Paweł II, Dzieła zebrane, t. 4, Kraków 2007, s. 643. 
Papież zachęca, aby życie traktować integralnie; na rok 2001 proponuje odczytanie życia jako powołania. Pisze:

Postrzeganie życia jako powołania sprzyja umocnieniu wewnętrznej wolności, podsycając w człowieku pragnienie przyszłości oraz skłaniając go do odrzucenia życia biernego, nudnego i banalnego. Życie zyskuje w ten sposób walor „daru otrzymanego, który ze swej natury chce się stać darem ofiarowanym"16.

Paradoksalnie, papież, który doświadcza trudu swoich lat i dolegliwości, zachęca do entuzjazmu, do podejmowania aktywności, która nie będzie aktywizmem, ale czerpaniem ze źródeł Bożej łaski. Przywołuje soborową zachętę z Gaudium et spes, aby odnajdować swoje powołanie w stawaniu się bezinteresownym darem z siebie dla innych. To wezwanie dotyczy prezbiterów, jak również wszystkich wierzących ${ }^{17}$.

Ostatnie orędzie Powołani, aby wypłynać na głębię na rok 2005 staje się niejako testamentem. Papież zachęca do przeciwstawieniu się mentalności zniechęcenia w obliczu niepowodzeń i trudności. Jako drogę zaufania wskazuje modlitwę; modlitwa bowiem jest miarą autentycznego życia chrześcijańskiego. Modlitwa staje się wypełnieniem Chrystusowego zaproszenia: „Trwajcie we Mnie, a Ja w was trwać będę” $(\mathrm{J} 15,4)$. Modlitwa pozwala doświadczać bliskości Zbawiciela nawet w obliczu niepowodzeń czy poczucia bezużyteczności. Jan Paweł II prowadzi do odkrywania serca swojej egzystencji poprzez Serce Jezusa; pisze w swoim orędziu:

Ten, kto otwiera serce Jezusowi nie tylko rozumie tajemnicę Jego egzystencji, ale także tajemnicę własnego powołania oraz wydaje dojrzałe owoce łaski. Pierwszym z tych owoców jest wzrastanie w świętości poprzez rozwój duchowy, który - zapoczątkowany w darze chrztu świętego - prowadzi do osiągnięcia doskonałej miłości ${ }^{18}$.

16 Jan Paweł II, Orędzie na XXXVII Światowy Dzień Modlitw o Powołania - 2001 roku, w: Jan Paweł II, Dzieła zebrane, t. 4, Kraków 2007, s. 651.

17 Jan Paweł II, Orędzie na XXXVII Światowy Dzień Modlitw o Powołania - 2001 roku, dz. cyt., s. 652 .

18 Jan Paweł II, Orędzie na XLII Światowy Dzień Modlitwo Powołania - 2005 r., w: Jan Paweł II, Dzieła zebrane, t. 4, Kraków 2007, s. 667. 
W tym samym orędziu przypomni o potrzebie świętych kapłanów, o konieczności pogłębionej refleksji na temat podstawowych wartości życia i realizacji swego osobistego i wspólnotowego powołania.

Refleksja Jana Pawła II na temat natury powołania i jego realizacji jest na wskroś sakramentalna. W swojej książce Wstańcie, chodźmy! papież snuje refleksję związaną z namaszczeniem Krzyżmem. Od chrztu świętego poprzez bierzmowanie, a w przypadku niektórych sakrament święceń, papież pokazuje na wspólną godność wszystkich powołań, ale jednocześnie zauważa konkret osobistej i wspólnotowej odpowiedzialności ${ }^{19}$. Godność i wybranie wymagają jednocześnie odpowiedzi w życiu, które nie jest podzielone na sfery zastrzeżone jedynie dla człowieka, czy wyłączone jedynie dla Boga; jedyną drogą do integralnego przyjęcia daru powołania jest pragnienie i dążenie do świętości ${ }^{20}$.

\section{Kapłan wobec współczesności}

Od 30 września do 28 października 1990 roku trwał Synod biskupów dotyczący formacji kapłańskiej we współczesnym świecie. Jego owocem stała się posynodalna adhortacja Pastores dabo vobis. Papież Jan Paweł II, podobnie jak w innych licznych dokumentach nawiązuje do dziedzictwa Soboru Watykańskiego II i zauważa jak wiele czasu poświęcono refleksji nad kapłaństwem służebnym. Zresztą jego przekaz w tym względzie jest niezwykle jasny i koherentny z dziedzictwem Vaticanum II. On nieustannie zauważa wartość kapłaństwa służebnego; kwestię sukcesji i powinności działania in persona Christi; permanentnie powtarza, że uczestnicy kapłaństwa służebnego są głosicielami słowa Bożego, szafarzami sakramentów i pasterzami Ludu Bożego. Jednocześnie niezmiennie podkreśla jedność ich misji z tymi wszystkimi, którzy mają udział w kapłaństwie królewskim na mocy sakramentu chrztu świętego ${ }^{21}$.

19 Zob. Jan Paweł II, Wstańcie, chodźmy!, Kraków 2004, s. 34-36.

20 Por. S. Zawada, Kapłaństwo, w: Jan Paweł II. Encyklopedia nauczania moralnego, red. J. Nagórny, K. Jeżyna, Radom 2005, s. 252-253.

${ }_{21}$ Por. B. Migut, Kapłaństwo, w: Encyklopedia katolicka, t. 8, red. B. Migut, Lublin 2000, k. 717. 
W adhortacji posynodalnej papież zauważa pilną potrzebę podjęcia tematu formacji do kapłaństwa i w trakcie posługi, pisze:

Wydaje się też, że kapłani, którzy od krótszego lub dłuższego czasu pełnią swoją posługę, cierpią dziś z powodu nadmiernego rozproszenia pośród stale rosnącej liczby obowiązków duszpasterskich; w obliczu trudnych problemów społecznych i kulturowych współczesności widzą konieczność powtórnego przemyślenia swego stylu życia i priorytetów pracy duszpasterskiej oraz uświadamiają sobie coraz bardziej potrzebę nieustannej formacji ${ }^{22}$.

U początku drogi formacji i coraz lepszego odczytywania swojej kapłańskiej tożsamości ciągle na pierwszym miejscu pozostaje konieczność upodobniania się do Chrystusa; naśladowania Go na drodze powołania. Jawi się tutaj konieczność radykalnego opowiedzenia się za ewangeliczną drogą, aby uczestniczyć w dziele zbawiania innych. Kapłan staje się coraz bardziej kapłanem świadomym, skąd wyszedł, Kogo niesie i głosi²3.

Papież zachęca do pogłębionego poznania kapłańskiej tożsamości wobec ciągle obecnych skutków błędnego odczytania soborowych koncepcji dotyczących kapłaństwa. Zwraca on uwagę na świadomość ontologicznego związku, który łączy kapłana z Chrystusem Najwyższym Kapłanem i Dobrym Pasterzem. Tożsamość kapłana ma swoje źródło w Trójcy Przenajświętszej, która objawia się i udziela w Jezusie Chrystusie. W tej niepowtarzalnej więzi objawia się charakter relacyjny tej tożsamości i posługi; kapłan zostaje sakramentalnie włączony we wspólnotę z biskupem i innymi prezbiterami, aby podjąć udział w dziele budowania jedności ${ }^{24}$. Jan Paweł II zauważa, że posługa kapłańska może być wypełniona tylko wtedy, gdy prezbiter jest zjednoczony z Chrystusem poprzez sakramentalne włączenie do stanu kapłańskiego i pozostaje w jedności hierarchicznej. Ojciec Święty nie waha się powiedzieć o konieczności radykalnej reformy wspólnoty, która będzie zdolna podejmować wspólne dzieła $^{25}$. Wielu obserwatorów pontyfikatu papieża z Polski podkreślało

22 Jan Paweł II, Adhortacja apostolska Pastores dabo vobis, w: Jan Paweł II, Dzieła zebrane, t. 2, Kraków 2007, s. 329.

${ }_{23}$ Por. J. Ambaum, Tożsamość kapłana, w: Kapłaństwo, red. P. Góralczyk, Poznań 1988, s. 222-223.

24 Jan Paweł II, Adhortacja apostolska Pastores dabo vobis, dz. cyt., s. 339.

25 Por. Jan Paweł II, Adhortacja apostolska Pastores dabo vobis, dz. cyt., s. 343. 
i podkreśla, iż jego słowo, pisane, czy mówione, było zawsze kierowane $\mathrm{z}$ wielkim zaangażowaniem $\mathrm{w}$ stronę znanego mu odbiorcy ${ }^{26}$. Zatem potrzeba jedności prezbiterium jest niezbędna, aby skutecznie realizować posługę słowa i sakramentów.

W perspektywie całego głoszenia Ewangelii pojawia się postulat zmierzania do pierwotnej harmonii między Bogiem a ludźmi oraz pomiędzy ludźmi, a także harmonii w sercu człowieka. To kwestia prawdziwego pokoju, którego nie może dać świat (por. J 14, 27). Ojciec Święty w adhortacji ukazuje jedność życia duchowego ze sprawowaniem posługi. Zauważa, że powołanie i wybranie ma służyć misji sakramentalnej. Wezwanie z liturgii święceń, aby życie dostosować do tajemnicy Krzyża Pańskiego jest ciągle aktualne, bowiem prezbiter staje się szafarzem Bożych tajemnic. Papież pokazuje jedność życia duchowego i posługi:

Związek pomiędzy życiem duchowym, a sprawowaniem posługi kapłańskiej można wyjaśnić poprzez miłość pasterską będącą darem sakramentu święceń. Posługa prezbitera, właśnie dlatego, że jest udziałem w zbawczej posłudze Jezusa Chrystusa Głowy i Pasterza, musi na nowo wyrażać i urzeczywistniać Jego miłość pasterską, która stanowi zarazem źródło i ducha służby kapłana oraz jego daru z siebie ${ }^{27}$.

Jakże konieczne wydaje się powracanie do obiektywnego źródła posługi kapłańskiej; wtedy na dalszy plan schodzi choćby kwestia samotności kapłańskiej, czy duszpasterskiego wypalenia. W tej perspektywie widać skąd kapłan czerpie siły i komu posługuje.

Rys świadectwa w posłudze Jana Pawła II jest jedną z cech charakterystycznych jego pontyfikatu. Wielu zauważało, iż nigdy nie zasłaniał on swoją osobą Jezusa Chrystusa, choć w swojej posłudze był znakomity, jeżeli chodzi o stronę medialną. Nie najdziemy także w jego nauczaniu moralizowania, które było wielkim problemem duszpasterskim, przez dziesiątki lat i skutecznie odstręczało wielu od wejścia na drogę ewangeliczną. Papież także wobec kapłanów nie stosuje żadnych form moralizowania, ale wskazuje na źródło uświęcenia i umocnienia. Pisząc o sprawowaniu sakramentów i celebrowaniu Liturgii godzin, zachęca do głębokiej

26 Por. Z. Struzik, Wartość słowa u Jana Pawła II, w: Słowo we współczesnej kulturze, red. W. Kawecki, Warszawa 2009, s.126.

${ }^{27}$ Jan Paweł II, Adhortacja apostolska Pastores dabo vobis, dz. cyt., s. 351. 
jedności między posługą i własnym życiem duchowym. W Pastores dabo vobis pisze:

Dar łaski ofiarowany Kościołowi staje się początkiem świętości i wezwaniem do uświęcenia także kapłana. Zarówno w jego posłudze, jak i w życiu duchowym miejsce naprawdę centralne zajmuje Eucharystia, ponieważ w niej „zawiera się całe duchowe dobro Kościoła, a mianowicie sam Chrystus, nasza Pascha i chleb żywy, który przez Ciało swoje ożywione i ożywiające Duchem Świętym daje życie ludziom, zapraszając ich $\mathrm{i}$ wprowadzając w ten sposób do ofiarowania razem z Nim samych siebie, swojej pracy i wszystkich rzeczy stworzonych"28.

Ta jedność z Chrystusem ma objawiać się również w posłudze sakramentu pokuty wobec wiernych, ale także w korzystaniu przez kapłanów z tego sakramentu, aby stawać się świadkami miłosierdzia Bożego.

\section{Posługa słowa}

Życie duchowe kapłana jest powiązane z posługą słowa, posługą sakramentu i służbą Miłości, czyli samemu Bogu. Kaznodzieja jest świadkiem Chrystusa poprzez zjednoczenie z Nim. Nie chodzi tu tylko o dobry przykład, ale o ukazanie doświadczenia Boga - Miłości, które przekracza poczucie obowiązku, doświadczenie emocjonalne, czy siłę woli. Zjednoczenie z Chrystusem jest zgodą na dzielenie losu Zbawiciela, w które wpisane jest cierpienie, odrzucenie, czy prześladowanie, nawet wobec niebezpieczeństwa śmierci. Tylko wtedy objawia się waga słowa i jego niezmienność ${ }^{29}$. Jan Paweł II w adhortacji Pastores dabo vobis stwierdza, że kapłan jest na pierwszym miejscu szafarzem słowa Bożego, aby prowadzić do poznania i uczestniczenia w tajemnicy Boga, która się odkrywa w Jezusie Chrystusie.

Dlatego przede wszystkim kapłan powinien rozwijać wielką osobistą zażyłość ze słowem Bożym. Nie może poprzestać na poznaniu aspektów językowych czy egzegetycznych, chociaż jest to konieczne; z sercem uległym i rozmodlonym musi zbliżać się do Słowa, aby ono do głębi przenikało jego myśli i uczucia i zrodziło w nim nową mentalność, „zamysł Chrystusowy” (1 Kor 2,16) - tak aby jego słowa,

\footnotetext{
28 Jan Paweł II, Adhortacja apostolska Pastores dabo vobis, dz. cyt., s. 353.

29 Por. G. Siwek, Kaznodzieja jako świadek, w: Sługa słowa, red. W. Przyczyna, Kraków 1997, s. 102-103.
} 
a jeszcze bardziej jego decyzje i postawy były coraz bardziej wyrazistym głoszeniem i świadectwem Ewangelii ${ }^{30}$.

W nauczaniu Jana Pawła II ujawnia się konieczność osobistego spotkania sługi słowa ze Słowem - Jezusem Chrystusem; stąd także płynie umiejętność mistagogicznego towarzyszenia wiernym i podprowadzania ich ku osobistemu spotkaniu ze Zbawicielem. Mistagogia może się realizować tylko wtedy, jeżeli sługa Słowa sam wchodzi do szkoły Jezusa i przyjmuje Jego formację. Sam Jezus przecież wprowadza uczniów w sposób myślenia Boga; myślenia, ale także działania ${ }^{31}$. Papież powie, że głosiciel ma być pierwszym, który wierzy w Słowo; on ma mieć świadomość, że treść przekazu nie jest jego, ale jest darem jemu powierzonym. Jan Paweł II stwierdzi nawet, iż głosiciel jest dłużnikiem Ludu Bożego, zatem nie może nie głosić i nie może nigdy zapominać o słuchaczach ${ }^{32}$.

Jan Paweł II w swoim nauczaniu ukazuje uprzywilejowaną przestrzeń głoszenia słowa Bożego i sprawowania sakramentów, którą jest parafia. W Liście do kapłanów na Wielki Czwartek 1986 roku przywołuje osobę św. Jana Marii Vianeya z racji 200-lecia jego urodzin. Nawiązując do ofiarnej posługi skromnego kapłana zauważa, iż jego nauczanie było wielką misją, aby przywrócić wiernych ku źródłu Bożej miłości. Święty Jan w swojej działalności kapłańskiej nieustannie wskazuje na Serce Jezusowe, $\mathrm{z}$ wielkim radykalizmem realizując $\mathrm{w}$ posłudze odpowiedzialność za powierzonych sobie wiernych. Papież pisze, że posługa Proboszcza z Ars w sposób zdumiewający przypomina niektóre opisy ewangeliczne. Nie bez znaczenie pozostaje także milczące świadectwo wiary, które wyraża się obecnością i wiarygodnością jego posługi ${ }^{33}$.

30 Jan Paweł II, Adhortacja apostolska Pastores dabo vobis, dz. cyt., s. 353.

31 Por. W. Świarzawski, Kaznodzieja jako mystagog, w: Stuga słowa, red. W. Przyczyna, Kraków 1997, s. 110.

32 Por. Jan Paweł II, Adhortacja apostolska Pastores dabo vobis, dz. cyt., s. 353.

33 Por. Jan Paweł II, List do kapłanów na Wielki Czwartek 1986 roku, w: Jan Paweł II, Dzieła zebrane, t. 3, Kraków 2007, s. 948-950. 


\section{Maryja - Matka kapłanów}

W bogactwie pontyfikatu św. Jana Pawła II ważne znaczenie ma jego oddanie się osobiście i oddanie spraw Kościoła Chrystusowej Matce. W dniu 25 marca 1987 roku podpisał encyklikę Redemptoris Mater o Błogosławionej Maryi Dziewicy w życiu pielgrzymującego Kościoła. Tym tekstem wprowadził także wierzących w Rok Maryjny, który rozpoczął się w niedzielę Zesłania Ducha Świętego 1987 roku i trwał do Wniebowzięcia Najświętszej Maryi Panny 1988 roku. Papież pisze, iż w Maryi Kościół widzi swój początek i zauważa jak bardzo tajemnica Niepokalanego Poczęcia Maryi prowadzi ku tajemnicy Paschalnej. Papież widzi Maryję w tajemnicy Chrystusa, a z tego wynika Jej szczególny związek z Kościołem. Ojciec Święty zaprasza, aby z Maryją pójść pielgrzymką wiary i na tej drodze doświadczyć osobistego spotkania z Jezusem Chrystusem ${ }^{34}$. Droga wiary Maryi i Jej towarzyszenie Synowi stały się kanwą Listu do kapłanów na rok 1988. Papież zwraca w nim uwagę na to, że w tożsamość kapłańską wpisana jest osoba Matki Bożej.

Kiedy działając in persona Christi sprawujemy sakrament zawsze tej samej i jedynej ofiary, w której Chrystus jest i pozostaje jedynym Kapłanem i Żertwą, nie zapominajmy o tym współcierpieniu Matki, w którym wypełniły się słowa Symeona ze świątyni jerozolimskiej „Twoją duszę miecz przeniknie” (Łk 2, 35). Słowa te były skierowane wprost do Maryi czterdziestego dnia po narodzeniu Jezusa. Na Golgocie, pod Krzyżem słowa te wypełniły się do końca. Gdy Syn Jej na Krzyżu objawił się w całej pełni jako „znak, któremu sprzeciwiać się będą” (Łk 2, 34) wówczas Jego wyniszczenie, ta śmiertelna agonia Syna, dosięgła też i matczynego Serca Maryi ${ }^{35}$.

W tych słowach zawiera się istota jedności ze Zbawicielem. Ojciec Święty zwracając się do kapłanów nawiązuje również do sceny powierzenia Maryi św. Janowi. Te wydarzenia z historii zbawienia stoją u źródła tożsamości kapłańskiej i posługi, którą kapłani realizują. Z jedności serca z Chrystusem z Jego Matką płynie natchnienie ku świętości, która

34 Por. Jan Paweł II, Encyklika Redemptoris Mater, w: Jan Paweł II, Dzieła zebrane, t. 2, Kraków 2007, s. 235-237.

35 Jan Paweł II, List do kapłanów na Wielki Czwartek 1988 roku, w: Jan Paweł II, Dzieła zebrane, t. 3, Kraków 2007, s. 964. 
staje się darem dla innych i odpowiedzialności za powierzone szafarstwo i świadectwo.

\section{Bibliografia}

Ambaum J., Tożsamość kapłana, w: Kapłaństwo, Poznań 1988, s. 209-223.

Jan Paweł II, Adhortacja apostolska Pastores dabo vobis, w: Jan Paweł II, Dzieła zebrane, t. 2, Kraków 2007, s. 325-417.

Jan Paweł II, Dar i tajemnica, Kraków 2005, s. 70.

Jan Paweł II, Encyklika Redemptoris Mater o Błogosławionej Maryi Dziewicy w życiu pielgrzymującego Kościoła, w: Jan Paweł II, Dzieła zebrane, t. 2, Kraków 2007, s. 233-275.

Jan Paweł II, List apostolski Dominicae cenae o tajemnicy i kulcie Eucharystii do kapłanów na Wielki Czwartek 1980 roku, w: Jan Paweł II, Dzieła zebrane, t. 3, Kraków 2007, s. 911-928.

Jan Paweł II, List apostolski Mane nobiscum Domine, Kraków 2004.

Jan Paweł II, List do kapłanów na Wielki Czwartek 1983 roku, w: Jan Paweł II, Dzieła zebrane, t. 3, Kraków 2007, s. 935-939.

Jan Paweł II, List do kapłanów na Wielki Czwartek 1986 roku, w: Jan Paweł II, Dzieła zebrane, t. 3, Kraków 2007, s. 947-955.

Jan Paweł II, List do kapłanów na Wielki Czwartek 1988 roku, w: Jan Paweł II, Dzieła zebrane, t. 3, Kraków 2007, s. 963-969.

Jan Paweł II, List do kapłanów na Wielki Czwartek 2004 roku, w: Jan Paweł II, Dzieła zebrane, t. 3, Kraków 2007, s. 1042-1045.

Jan Paweł II, Orędzie na XIX Światowy Dzień Modlitw o Powołania - 1982 r., w: Jan Paweł II, Dzieła zebrane, t. 4, Kraków 2007, s. 582-584.

Jan Paweł II, Orędzie na XLII Światowy Dzień Modlitw o Powołania - 2005 r., w: Jan Paweł II, Dzieła zebrane, t. 4, Kraków 2007, s. 667-669.

Jan Paweł II, Orędzie na XXXIV Światowy Dzień Modlitw o Powołania - 1999 r., w: Jan Paweł II, Dzieła zebrane, t. 4, Kraków 2007, s. 642-646.

Jan Paweł II, Orędzie na XXXVII Światowy Dzień Modlitw o Powołania - 2001 r., w: Jan Paweł II, Dzieła zebrane, t. 4, Kraków 2007, s. 651-655.

Jan Paweł II, Wstańcie, chodźmy!, Kraków 2004.

Łysień L., Indywidualizm, w: Jan Paweł II. Encyklopedia nauczania społecznego, red. A. Zwoliński, Radom 2005, s. 198-203.

Migut B., Kapłaństwo, w: Encyklopedia katolicka, t. 8, red. B. Migut, Lublin 2000, k. 715-718.

Siwek G., Kaznodzieja jako świadek, w: Sługa słowa, red. W. Przyczyna, Kraków 1997, s. 83-108.

Struzik Z., Wartość słowa u Jana Pawła II, w: Słowo we współczesnej kulturze, Warszawa 2009, s. 107-128. 
Sobór Watykański II, Konstytucja dogmatyczna o Kościele Lumen gentium, w: Sobór Watykański II, Konstytucje, dekrety, deklaracje, tekst polski, nowe tłum., red. M. Przybył, Poznań 2002, s. 104-166.

Świerzawski W., Kaznodzieja jako mystagog, w: Sługa słowa, red. W. Przyczyna, Kraków 1997, s. 109-118.

Zawada S., Kapłaństwo, w: Jan Paweł II. Encyklopedia nauczania moralnego, red. J. Nagórny, K. Jeżyna, Radom 2005, s. 251-255. 